\title{
In vitro and in situ activity of carboxymethyl cellulase and glutamate dehydrogenase according to supplementation with different nitrogenous compounds ${ }^{1}$
}

\author{
Isabela Pena Carvalho de Carvalho², Edenio Detmann ${ }^{3}$, Mário Fonseca Paulino ${ }^{3}$, Hilário \\ Cuquetto Mantovani ${ }^{4}$, Sebastião de Campos Valadares Filho ${ }^{3}$, Daiany Iris Gomes ${ }^{5}$, Viviane \\ Aparecida Carli Costa ${ }^{6}$
}

\footnotetext{
1 This paper had financial support from FAPEMIG (PPM), CNPq and INCT - Ciência Animal.

2 Programa de Pós-Graduação em Zootecnia, Universidade Estadual Paulista, Jaboticabal-SP.

${ }^{3}$ Departamento de Zootecnia, Universidade Federal de Viçosa, Viçosa-MG. Researcher from CNPq and INCT - Ciência Animal.

${ }^{4}$ Departamento de Microbiologia, Universidade Federal de Viçosa, Viçosa-MG. Researcher from CNPq.

5 Programa de Pós-Graduação em Zootecnia, Universidade Federal de Viçosa, Viçosa-MG.

${ }^{6}$ LZNA, Universidade Estadual do Norte Fluminense, Campos dos Goytacazes-RJ.
}

\begin{abstract}
Two experiments were carried out to evaluate the effect of supplementation with different nitrogenous compounds on the activities of carboxymethil cellulase (CMCase) and glutamate dehydrogenase (GDH). In the first experiment, four treatments were evaluated in vitro: cellulose, cellulose with casein, cellulose with urea, and cellulose with casamino acids. After 6, 12 and 24 hours of incubation, CMCase and GDH activity, pH, and concentrations of ammonia nitrogen (AN) and microbial protein were measured. In the three incubation periods, the concentration of AN was higher when urea was used as a supplemental source of nitrogen. The activity of CMCase was higher with the addition of urea and casamino acids when compared with the control and the casein treatment. Supplementation with casamino acids provided higher GDH activity when compared with the control at 6 hours of incubation. At 12 hours of incubation, the GHD activity was also stimulated by casein. At 24 hours, there was no difference in GHD activity among treatments. In the second experiment, three rumen-fistulated bulls were used for in situ evaluation. Animals were fed Tifton hay (Cynodon sp.) ad libitum. The treatments consisted of control (no supplementation), supplementation with non-protein nitrogenous compounds (urea and ammonium sulphate, 9:1) and supplementation with protein (albumin). In treatments with nitrogenous compound supplementation, $1 \mathrm{~g}$ of crude protein $/ \mathrm{kg}$ of body weight was supplied. The experiment was conducted in a $3 \times 3$ Latin square design. The measurements were performed at 6,12 and 24 hours after supplementation. No difference in GDH activity was observed among treatments. The control treatment showed higher CMCase activity when compared with the treatments containing supplemental sources of nitrogen. However, urea supplementation provided higher CMCase activity compared to albumin.
\end{abstract}

Key Words: fibrolytic enzymes, nitrogen assimilation, protein effect, rumen microbiology

\section{Introduction}

Several in vitro studies have concluded that supplementation with true protein causes deleterious effects on the degradation of neutral detergent fiber (NDF) from high-quality forage (Paez-Bernal, 2007; Costa et al., 2009; Zorzi et al., 2009). That negative effect of true protein supplementation was called "protein effect" (Costa et al., 2009) and would not be observed upon the addition of urea to the medium (Paez-Bernal, 2007; Zorzi et al., 2009).

Different hypotheses have been established to support the negative effects of true protein supplementation. One hypothesis involves a change in the balance of ATP-dependent and -independent enzymatic systems during microbial nitrogen assimilation (Paulino et al., 2008).
Different enzymatic systems may be used for ammonia assimilation and the predominance of a particular system depends on the extracellular concentration of ammonia nitrogen (AN) and its intracellular accumulation. The assimilatory pathway with the greatest affinity for ammonia in the rumen utilizes the enzyme glutamine synthetaseglutamate synthase (GS-GOGAT) (Brown etal., 1974). Because the GS-GOGAT is ATP-dependent, if the AN concentration is low, the efficiency of microbial growth can be reduced by ATP being diverted from growth to nitrogen assimilation. When the concentration of AN is high, the main pathway for nitrogen assimilation is through glutamate dehydrogenase (GDH), which does not require ATP (White, 2000).

Therefore, the balance between enzymatic systems for nitrogen assimilation is intimately dependent on the 
concentration of AN in the rumen (Chalupa et al., 1969). Thus, an increase in the concentration of AN in the rumen provided by supplemental nitrogenous compounds could influence the energy available for the growth of microbial species that use AN preferentially, such as the fibrolytic bacteria.

However, studies on the degradation of fibrous carbohydrates with supplementation of different forms of nitrogen (protein and non-protein) are still necessary. The effects of these supplements on the activity of microbial enzymes involved in the assimilation of nitrogen and fiber degradation should be examined.

The objective of this study was to evaluate the effects of supplementation with different nitrogen sources on the in vitro and in situ activities of carboxymethyl cellulase (CMCase) and glutamate dehydrogenase (GDH).

\section{Material and Methods}

An in vitro assay and an in situ trial were conducted in the Laboratório de Nutrição Animal and Laboratório de Microbiologia Anaeróbica at the Universidade Federal de Viçosa.

For the in vitro assay the rumen content used as inoculum was obtained from a crossbred rumen-fistulated Holstein-Zebu steer ( $350 \mathrm{~kg}$ of body weight). This steer was continuously fed a diet composed of signal grass (Brachiaria decumbens) pasture during the rainy season (December 2007 to February 2008) and $200 \mathrm{~g}$ /day of supplemental crude protein $(\mathrm{CP})$. Two-thirds of the $\mathrm{CP}$ were in the form of albumin (true protein) and $1 / 3$ was in the form of urea (non-protein nitrogen). Supplement was provided daily via rumen infusion at 12 p.m.

The liquid portion of the rumen content was collected through the fistula at 11 a.m. (after morning grazing, but before supplement infusion), filtered through three layers of cheesecloth and allowed to settle in an Erlenmeyer flask for $30 \mathrm{~min}$ at $39^{\circ} \mathrm{C}$ for separation of fluid and particulate phases.

The fluid obtained was anaerobically transferred to test tubes and centrifuged $(3,000 \times \mathrm{g} / 5 \mathrm{~min})$. The supernatant was discarded and the cell pellet was re-suspended in a basal medium containing, per litre: $4 \mathrm{~g}$ of glucose, $292 \mathrm{mg}$ of $\mathrm{K}_{2} \mathrm{HPO}_{4}, 480 \mathrm{mg}$ of $\left(\mathrm{NH}_{4}\right)_{2} \mathrm{SO}_{4}, 480 \mathrm{mg}$ of $\mathrm{NaCl}, 100 \mathrm{mg}$ of $\mathrm{MgSO}_{4} .7 \mathrm{H}_{2} \mathrm{O}, 64 \mathrm{mg}$ of $\mathrm{CaCl}_{2} \cdot 2 \mathrm{H}_{2} \mathrm{O}, 500 \mathrm{mg}$ of cysteine, $1 \mathrm{~g}$ of trypticase, $4 \mathrm{~g}$ of $\mathrm{Na}_{2} \mathrm{CO}_{3}, 0.5 \mathrm{~g}$ of yeast extract, $177 \mu \mathrm{L}$ of acetic acid, $63 \mu \mathrm{L}$ of propionic acid, $31 \mu \mathrm{L}$ of butyric acid, $11 \mu \mathrm{L}$ of valeric acid, $11 \mu \mathrm{L}$ of isovaleric acid and $11 \mu \mathrm{L}$ of isobutyric acid. After standardisation of the optical density $\left(\mathrm{DO}_{600 \mathrm{~nm}}\right)$ to 2.00 , the cellular suspension was used to inoculate the tubes used for in vitro incubations.
Portions of microcrystalline cellulose (Avicel ${ }^{\circledR}$ ) $(600 \mathrm{mg}$ ) were placed in $100-\mathrm{mL}$ glass flasks. The nitrogen source was then added to a final concentration of $4 \mathrm{mg} \mathrm{CP} / \mathrm{mL}$ for all the treatments involving nitrogen supplementation (Zorzi et al., 2009).

Four treatments were evaluated, which included cellulose, cellulose with casein, cellulose with urea, and cellulose with casamino acids (Table 1).

The sources of urea, ammonium sulphate, casein and casamino acids were Isofar ${ }^{\circledR} 744$, Merck $^{\circledR}$ A596117611, Sigma ${ }^{\circledR}$ C7078 and Sigma ${ }^{\circledR}$ C2427, respectively.

Forty-eight millilitres of the basal medium were added to the incubation flasks which were maintained under constant flow of $\mathrm{CO}_{2}$ to assure an anaerobic environment. Twelve millilitres of the ruminal inoculum were added. Flasks were immediately sealed and kept at $39{ }^{\circ} \mathrm{C}$ under orbital agitation $(40 \mathrm{rpm})$. Fermentation gases were removed every three hours.

After 24 hours of incubation, the containers were opened under an atmosphere of $\mathrm{CO}_{2}$ and their contents were used as inoculum for a new incubation, while maintaining the treatment of the first incubation. After the transfer, one flask of each treatment was taken at 6,12 and 24 hours of incubation and the enzymes were extracted according to the method described by Silva et al. (1987).

The contents of the flasks were transferred to test tubes and centrifuged $(120 \times \mathrm{g} / 15 \mathrm{~min})$. The supernatant was discarded to remove microorganisms that had not adhered to the particles. One gram of the pellet was transferred to a beaker and the remainder of the pellet was oven-dried $\left(105^{\circ} \mathrm{C} / 16\right.$ hours) to obtain the dry matter (DM) content.

To the moist residue, $10 \mathrm{~mL}$ of a sodium phosphate solution (10 mM, pH 6.8), $25 \mu \mathrm{L}$ of mercaptoethanol and $125 \mu \mathrm{L}$ of $0.4 \%$ lysozyme (Farenzena et al., 2008) were added and the solution was placed in a water bath at $37^{\circ} \mathrm{C}$ for 3 hours. The fibrous portion was removed by centrifugation $\left(1000 \times \mathrm{g} / 15 \mathrm{~min} ; 4^{\circ} \mathrm{C}\right)$ and the supernatant was used to estimate the activity of CMCase and GDH.

Table 1 - Description of the compounds added to in vitro system according to the treatments

\begin{tabular}{lcccc}
\hline & \multicolumn{4}{c}{ Treatments } \\
\cline { 2 - 5 } Compound & C & CC & CUR & CCA \\
\hline Cellulose (mg) & 600 & 600 & 600 & 600 \\
Casein (mg) & & 303.0 & & \\
Urea:Ammonium sulphate, 9:1 (mg) & & & 93.6 & 351.0 \\
Casamino acids (mg) & 12 & 12 & 12 & 12 \\
Inoculum (mL) & 48 & 48 & 48 & 48 \\
Basal medium (mL) & & & & \\
\hline C - cellulose; CC - cellulose and casein; CUR - cellulose and urea; CCA - \\
cellulose and casamino acids.
\end{tabular}

R. Bras. Zootec., v.41, n.3, p.683-691, 2012 
To quantify the CMCase activity, the method described by Miller et al. (1960) was used. In this process, $1 \mathrm{~mL}$ of the enzyme extract was incubated at $50^{\circ} \mathrm{C}$ for 20 min with $1 \mathrm{~mL}$ of a carboxymethyl cellulose solution. This solution contained, per litre: $11.2 \mathrm{~g}$ of carboxymethyl cellulose, $7 \mathrm{~g}$ of citric acid, $19.6 \mathrm{~g}$ of dihydrate sodium citrate, $400 \mathrm{mg}$ of merthiolate and $400 \mathrm{mg}$ of glucose. After the incubation period, tubes were cooled with tap water and $3 \mathrm{~mL}$ of DNS solution was added. The DNS solution consisted of $10 \mathrm{~g}$ of dinitrosalicylic acid, $300 \mathrm{~g}$ of the salt of Rochelle, $500 \mathrm{~mL}$ of distilled water and $300 \mathrm{~mL}$ of $2 \mathrm{M} \mathrm{NaOH}$. For every $20 \mathrm{~mL}$ of the DNS reagent, $28 \mu \mathrm{L}$ of $5 \%$ phenol and $80 \mu \mathrm{L}$ of $35 \%$ sodium metabisulfite were added to the solution. Tubes were incubated in boiling water for $15 \mathrm{~min}$, cooled and absorption was determined spectrofotometrically at $540 \mathrm{~nm}$.

The activity of CMCase was calculated from the amount of reducing sugars released after the incubation period of the enzyme with the substrate. A standard curve was generated from solutions containing $0.3,0.6,1.2,3.0,4.2$, 5.4 , and $6.0 \mathrm{mM}$ of glucose.

The GDH activity was evaluated according to the method described by King (1974). In the test tubes, $500 \mu \mathrm{L}$ of a 2-oxoglutarate solution (14 mg of 2-oxaloglutarate in $100 \mathrm{~mL}$ of $0.067 \mathrm{M}$ sodium phosphate buffer at $\mathrm{pH} 7.0$ ), $500 \mu \mathrm{L}$ of an ammonium sulphate solution (3.96 g of $\left(\mathrm{NH}_{4}\right)_{2} \mathrm{SO}_{4}$ in $100 \mathrm{~mL}$ of $0.067 \mathrm{M}$ sodium phosphate buffer at pH 7.0) and $200 \mu \mathrm{L}$ of enzyme extract were added. Tubes were initially incubated in water bath at $37^{\circ} \mathrm{C}$ and a solution of $0.4 \mathrm{mM} \mathrm{NADH}(200 \mu \mathrm{L})$ was added. Tubes were then incubated at $37^{\circ} \mathrm{C}$ for $60 \mathrm{~min}$. After the incubation period, $1 \mathrm{~mL}$ of a ketone $(200 \mathrm{mg} / \mathrm{L}$ of 2,4-dinitrophenylhydrazine in $1 \mathrm{~N} \mathrm{HCl}$ ) was added and the tubes were incubated for $20 \mathrm{~min}$. Finally, $10 \mathrm{~mL}$ of $0.4 \mathrm{~N} \mathrm{NaOH}$ were added and the absorbance was measured at $390 \mathrm{~nm}$.

Enzyme activity was calculated as the difference between the tubes containing samples and a blank tube. In the blank tube, the 2-oxoglutarate solution was added after incubation for $60 \mathrm{~min}$. To generate the standard curve, the standard solution of $0.96 \mathrm{mMNADH}\left(8.5 \mathrm{mg}\right.$ of NADH-Na ${ }_{2}$ in $10 \mathrm{~mL}$ of the 2-oxoglutarate solution) was used.

The GDH activity was defined in "arbitrary units", where each enzyme unit was equivalent to a variation of $1 \mathrm{nmol}$ in the concentration of 2-oxoglutarate $/ \mathrm{mL} / \mathrm{min}$ (King, 1974).

A second set of flasks was inoculated and sampled at 6,12 and 24 hours to quantify the concentration of AN and microbial protein, from which $1.5-\mathrm{mL}$ samples were collected and stored at $-15^{\circ} \mathrm{C}$ and the concentration of AN was then estimated (Chaney and Marbach, 1962). The concentration of microbial protein was evaluated using the dye method described by Bradford et al. (1976).

The incubation procedures and subsequent evaluations were conducted three times for each treatment. Data were evaluated for normality and homoscedasticity, according to the Lilliefors and Bartlett tests, respectively $(\alpha=0.05)$. It was anticipated that the concentration of microbial protein and the CMCase and GDH activities did not follow those basic assumptions $(\mathrm{P}<0.05)$ and were transformed based on the natural logarithm scale. After transformation, the conditions of normality and homoscedasticity $(\mathrm{P}>0.05)$ were verified. After this procedure, the data were analysed by analysis of variance, according to a randomized block design, where the incubations were considered blocks, with four treatments $(\alpha=0.05)$. The comparisons between treatments were done using the Fisher's least significant difference (LSD). The statistical procedures were performed using the PROC GLM of SAS (Statistical Analysis System, version 9.1).

In the in situ trial, three crossbred rumen-fistulated Holstein-Zebu bulls, with an average body weight of $351 \pm 8 \mathrm{~kg}$ were kept in individual stalls, feeding on Tifton hay (Cynodon sp.) ad libtum (89.4\% of DM, $13.6 \%$ of CP, $73.0 \%$ of neutral detergent fiber, and $3.0 \%$ of lignin). Animals were adapted to the handling and forage for a period of seven days.

The treatments included a control (no supplementation) diet, supplementation with non-protein nitrogenous compounds and supplementation with true protein. In the treatments with nitrogenous compound supplementation, $1 \mathrm{~g}$ of CP was supplied per $\mathrm{kg}$ of body weight, which corresponds to $60 \%$ of the rumen degradable protein required for a bull with a body weight of $350 \mathrm{~kg}$ and daily weight intake of $1 \mathrm{~kg}$ (Marcondes et al., 2010). Albumin (Maximus, Arve Alimentos) and urea (urea and ammonia sulphate, 9:1) were used as sources of true protein and non-protein nitrogenous compounds, respectively. The supplements were introduced daily into the rumen at $12 \mathrm{p} . \mathrm{m}$.

The experiment was conducted in a $3 \times 3$ Latin square design, with three 7-day experimental periods. The first five days of each period were allotted to adapt the ruminal environment to supplementation.

In order to assess the $\mathrm{pH}$ and $\mathrm{AN}$ concentration in the rumen, on the sixth day of each experimental period samples of ruminal fluid were collected at 6,12 and 24 hours after supplementation. Samples were manually collected at the liquid-solid interface of the rumen mat and filtered through three layers of cheesecloth. The $\mathrm{pH}$ was evaluated with a digital potentiometer (Digimed ${ }^{\circledR} \mathrm{DM}-2 \mathrm{P}$ ). A 40-mL aliquot was then separated, fixed with $1 \mathrm{~mL} \mathrm{H}_{2} \mathrm{SO}_{4}(1: 1)$ and frozen at $-15{ }^{\circ} \mathrm{C}$ for further evaluation of $\mathrm{AN}$ concentration. 
The in situ incubation for the quantification of CMCase and GDH activity was simultaneously conducted. Hay samples were processed in a Wiley mill (2-mm) and cell contents were extracted to isolate the insoluble fibrous fraction (Mertens, 2002). After drying $\left(60^{\circ} \mathrm{C}\right)$, samples of insoluble fiber were placed in non-woven textile $\left(100 \mathrm{~g} / \mathrm{m}^{2}\right)$ bags (Casali et al., 2008) in a ratio of $20 \mathrm{mg} / \mathrm{cm}^{2}$ of bag surface. Samples were incubated in duplicate in the rumen, with incubation times of 6,12 and 24 hours after supplementation. After removal, samples were frozen in an ultra-freezer at $-70{ }^{\circ} \mathrm{C}$ for subsequent analysis of enzymatic activity.

An enzyme extraction was conducted according to the method described for the in vitro assay. After thawing, $1 \mathrm{~g}$ of the fibrous residue was transferred to a beaker and the remaining residue was oven-dried $\left(105{ }^{\circ} \mathrm{C} / 16\right.$ hours $)$ to obtain DM content. Ten millilitres of sodium phosphate solution (10 mM, pH 6.8), $25 \mu \mathrm{L}$ of mercaptoethanol and $125 \mu \mathrm{L}$ of $0.4 \%$ lysozyme (Farenzena et al., 2008) were added to the moist residue and maintained in a water bath at $37{ }^{\circ} \mathrm{C}$ for 3 hours. The incubation contents were centrifuged $\left(1000 \times \mathrm{g} / 15 \mathrm{~min}, 4^{\circ} \mathrm{C}\right)$ and the fibrous portion was removed by filtration through a triple layer of cheesecloth. The liquid fraction was used to estimate the CMCase and GDH activities, as previously described.
After thawing, the rumen fluid samples were centrifuged at $1,000 \times \mathrm{g}$ for 10 minutes. The supernatant was analyzed for AN concentration according to colorimetric method of Chaney \& Marbach (1962).

Data were evaluated for normality and homoscedasticity, according to the Lilliefors and Bartlett tests, respectively $(\alpha=0.05)$. It was anticipated that the CMCase and GDH activities did not follow basic assumptions $(\mathrm{P}<0.05)$ and were transformed based on a natural logarithm. After the transformation, the conditions of normality and homoscedasticity $(\mathrm{P}>0.05)$ were verified. After this procedure, the data were analysed according to a $3 \times 3$ Latin square design as multivariate repeated measures over time by using a profile analysis (Curi, 1980; Littell et al., 1991) $(\alpha=0.05)$. The statistical procedures were performed using the PROC GLM of SAS (Statistical Analysis System, version 9.1)

\section{Results}

In the in vitro assay, after six hours of incubation, the AN concentration was higher $(\mathrm{P}<0.05)$ when urea was used as nitrogen source, while true protein sources (casein and casamino acids) did not increase the concentration of AN over the control $(\mathrm{P}>0.05)$ (Table 2$)$.

Table 2 - Concentration of ammonia nitrogen $(\mathrm{mg} / \mathrm{dL})$ and microbial protein $(\mathrm{mg} / \mathrm{mL})$ and activities of carboxymethil cellulase (nmol reducing sugar/g DM/min) and glutamate dehydrogenase (arbitrary units) according to incubation time (in vitro experiment)

\begin{tabular}{|c|c|c|c|c|c|}
\hline \multirow[b]{2}{*}{ Item } & \multicolumn{4}{|c|}{ Nitrogen source ${ }^{1}$} & \multirow[b]{2}{*}{$\mathrm{CV}(\%)$} \\
\hline & Control & Casein & Urea & Casamino acids & \\
\hline & & & 6 hours & & \\
\hline Ammonia nitrogen & $18.42 b$ & $36.84 b$ & $85.23 \mathrm{a}$ & $37.77 b$ & 28.9 \\
\hline Microbial protein & 246.5 & 299.7 & 310.2 & 264.6 & - \\
\hline Microbial protein ${ }^{2}$ & $5.408 b$ & $5.646 \mathrm{a}$ & $5.687 \mathrm{a}$ & $5.514 \mathrm{ab}$ & 1.8 \\
\hline CMCase & 1568.0 & 1792.3 & 2287.9 & 2285.7 & - \\
\hline CMCase $^{2}$ & $7.344 b$ & $7.455 \mathrm{ab}$ & $7.691 \mathrm{a}$ & $7.686 \mathrm{a}$ & 2.1 \\
\hline GDH & 23.97 & 24.37 & 24.22 & 24.61 & - \\
\hline \multirow[t]{2}{*}{$\mathrm{GDH}^{2}$} & $2.934 \mathrm{~b}$ & $2.941 \mathrm{ab}$ & $2.952 \mathrm{ab}$ & $2.971 \mathrm{a}$ & 0.5 \\
\hline & & & 12 hours & & \\
\hline Ammonia nitrogen & $15.98 \mathrm{c}$ & $50.19 b$ & $99.63 \mathrm{a}$ & $50.09 \mathrm{~b}$ & 7.3 \\
\hline Microbial protein & 325.6 & 360.1 & 459.4 & 314.5 & - \\
\hline Microbial protein ${ }^{2}$ & $5.672 \mathrm{a}$ & $5.866 \mathrm{a}$ & $6.104 \mathrm{a}$ & $5.736 \mathrm{a}$ & 4.9 \\
\hline CMCase & 2924.6 & 2024.6 & 3515.2 & 2695.6 & - \\
\hline $\mathrm{CMCase}^{2}$ & $7.929 \mathrm{ab}$ & $7.605 b$ & $8.108 \mathrm{a}$ & $7.872 \mathrm{ab}$ & 2.4 \\
\hline GDH & 24.47 & 24.81 & 24.63 & 24.79 & - \\
\hline \multirow[t]{2}{*}{$\mathrm{GDH}^{2}$} & $3.026 \mathrm{~b}$ & $3.041 \mathrm{a}$ & $3.036 \mathrm{ab}$ & $3.043 \mathrm{a}$ & 0.2 \\
\hline & & & 24 hours & & \\
\hline Ammonia nitrogen & $12.19 \mathrm{~d}$ & $77.5 b$ & $95.3 \mathrm{a}$ & $65.9 \mathrm{c}$ & 7.8 \\
\hline Microbial protein & 622.1 & 620.2 & 683.1 & 616.7 & - \\
\hline Microbial protein ${ }^{2}$ & $6.347 \mathrm{a}$ & $6.377 \mathrm{a}$ & $6.380 \mathrm{a}$ & $6.466 \mathrm{a}$ & 1.9 \\
\hline CMCase & 3799.8 & 3505.7 & 4654.2 & 4791.2 & - \\
\hline $\mathrm{CMCase}^{2}$ & $8.157 \mathrm{~b}$ & $8.100 \mathrm{~b}$ & $8.373 \mathrm{a}$ & $8.410 \mathrm{a}$ & 1.2 \\
\hline GDH & 22.25 & 21.42 & 22.67 & 20.85 & - \\
\hline $\mathrm{GDH}^{2}$ & $2.972 \mathrm{a}$ & $2.947 \mathrm{a}$ & $2.988 \mathrm{a}$ & $2.924 \mathrm{a}$ & 1.6 \\
\hline
\end{tabular}

CMCase - carboxymethil cellulose; GDH - glutamate dehydrogenase.

${ }^{1}$ Means in the row followed by different letters differ according to Fisher's LSD test $(\mathrm{P}<0.05)$.

${ }^{2}$ Data were transformed into natural logarithm scale. 
The concentration of microbial protein did not differ between supplements $(\mathrm{P}>0.05)$. However, the concentration of microbial protein was superior to the control when casein and urea were added $(\mathrm{P}<0.05)$ (Table 2$)$.

The activity of CMCase was stimulated by supplementation with urea and casamino acids $(\mathrm{P}<0.05)$ when compared with the control. Casein provided intermediate values when compared with these treatments (Table 2). Supplementation with casamino acids provided higher GDH activity $(\mathrm{P}<0.05)$ when compared with the control, while casein and urea showed intermediate values (Table 2).

After 12 hours of in vitro incubation, the concentration of AN was higher $(\mathrm{P}<0.05)$ when urea was included as a source of nitrogen (Table 2). However, unlike the conditions after 6 hours of incubation, the sources of protein (casein and casamino acids) caused an increase in the concentrations of AN when compared with the control $(\mathrm{P}<0.05)$. Differences in the concentration of microbial protein were not observed among treatments $(\mathrm{P}>0.05)$ (Table 2). After 12 hours of in vitro incubation, urea supplementation led to higher values of CMCase activity. However, the CMCase activity of the control and the treatment supplemented with casamino acids were similar $(\mathrm{P}<0.05)$, while the CMCase activity was reduced by casein $(\mathrm{P}<0.05)$. When compared with six hours of incubation, the GDH activity was also stimulated by casein (Table 2).

In the last in vitro incubation time (24 hours), supplementation with urea provided the highest concentration of AN, followed by casein, casamino acids and the control $(\mathrm{P}<0.05)$ (Table 2).

The concentration of microbial protein remained stable for all treatments after 12 and 24 hours of incubation $(\mathrm{P}>0.05)$ (Table 2). The activity of CMCase was greater with the use of urea and casamino acids $(\mathrm{P}<0.05)$ when compared with the control and casein, which did not differ $(\mathrm{P}>0.05)$ (Table 2). The GDH activity did not show any differences among treatments $(\mathrm{P}>0.05)$ (Table 2).

In the in situ trial, no effects of nitrogen source, time, or their interaction were observed $(\mathrm{P}>0.05)$ on the $\mathrm{AN}$ concentration or rumen $\mathrm{pH}$ (Table 3 ). The activity of CMCase was affected by the interaction of incubation time and nitrogen source $(\mathrm{P}<0.05)$. The source of nitrogen and time had an effect on GDH activity $(\mathrm{P}<0.05)$; however, there was no interaction of these factors $(\mathrm{P}>0.05)$ (Table 3$)$. The average $\mathrm{pH}$ of rumen fluid was 6.55 (Table 4 ).

Within six hours of in situ incubation, CMCase activity was found lower $(\mathrm{P}<0.05)$ with both nitrogenous compounds compared with the control (Table 4). However, albumin caused lower activity compared with urea $(\mathrm{P}<0.05)$. From six to twelve hours after supplementation, an increase in the CMCase activity was observed when urea was supplemented $(\mathrm{P}<0.05)$. Consequently, 12 hours after supplementation, CMCase activity in the control and with urea supplementation did not differ $(\mathrm{P}>0.05)$ but were higher than albumin $(\mathrm{P}<0.05)$ (Table 4).

From 12 to 24 hours after supplementation, the CMCase activity stabilized with urea supplementation $(\mathrm{P}>0.05)$ and increased in the control and with the addition of albumin $(\mathrm{P}<0.05)$ (Table 4). Thus, the CMCase activity did not differ for urea and albumin at 24 hours after supplementation $(\mathrm{P}>0.05)$; however, both nitrogen sources caused lower CMCase activity than the control $(\mathrm{P}<0.05)$ (Table 4).

Since there was no interaction between nitrogen source and time in the activity of GDH ( $>>0.05)$, only the marginal means of each treatment were compared. However, no difference among treatments $(\mathrm{P}>0.05)$ was observed (Table 4). In general, the GDH activity was increased in the intervals evaluated $(\mathrm{P}<0.05)$.

Although the source of nitrogen and incubation time did not affect the rumen concentration of AN by the level of significance used in this study $(\alpha=0.05)$, due to the relevance of this variable, a value of $\alpha=0.10$ was adopted in the evaluation of differences between treatments and incubation periods, given the levels of probability shown in Table 3.

The sources of nitrogen (urea and albumin) caused an increase $(\mathrm{P}<0.10)$ in the concentration of rumen $\mathrm{AN}$ compared with the control. The AN concentration decreased in all time intervals $(\mathrm{P}<0.10)$ (Table 5).

Table 3 - Descriptive levels of probability of type I error for the effects of nitrogen source, time after nitrogen supplementation and their interaction on ammonia nitrogen concentration, rumen $\mathrm{pH}$, and activities of carboxymethyl cellulase and glutamate dehydrogenase (in situ experiment)

\begin{tabular}{lccc}
\hline & & Effect & \\
\cline { 2 - 4 } Variable & Nitrogen source & Incubation time & Nitrogen source $\times$ incubation time \\
\hline Ammonia nitrogen & 0.0647 & 0.0771 & 0.2018 \\
Rumen pH & 0.7429 & 0.3584 & 0.6706 \\
CMCase $^{1}$ & 0.0001 & 0.0001 & 0.0060 \\
GDH $^{1}$ & 0.0111 & $<0.0001$ & 0.1082 \\
\hline
\end{tabular}

CMCase - carboxymethil cellulose; GDH - glutamate dehydrogenase.

${ }^{1}$ The dataset was evaluated after transformation into natural logarithm scale. 
Table 4 - Rumen pH and natural logarithms of carboxymethyl cellulase and glutamate dehydrogenase activities according to time after supplementation and nitrogen sources (in situ experiment)

\begin{tabular}{|c|c|c|c|c|c|c|}
\hline \multirow[b]{2}{*}{ Nitrogen source } & \multicolumn{5}{|c|}{ Time (hours) } & \multirow[b]{2}{*}{ Mean $^{1}$} \\
\hline & $6^{1}$ & $\Delta_{6-12}{ }^{2}$ & $12^{1}$ & $\Delta_{12-24^{2}}$ & $24^{1}$ & \\
\hline \multicolumn{7}{|c|}{ Rumen $\mathrm{pH}$} \\
\hline Control & 6.50 & -0.32 & 6.18 & +0.48 & 6.66 & 6.45 \\
\hline Albumin & 6.50 & +0.04 & 6.54 & +0.13 & 6.67 & 6.57 \\
\hline Urea & 6.52 & +0.14 & 6.66 & +0.06 & 6.72 & 6.63 \\
\hline Mean & - & -0.05 & - & +0.22 & - & \\
\hline \multicolumn{7}{|c|}{ Carboxymethyl cellulase activity (nmol reducing sugar/g DM/min) ${ }^{3}$} \\
\hline Control & $9.073 \mathrm{a}$ & -0.005 & $9.068 \mathrm{a}$ & $+0.220 *$ & $9.288 \mathrm{a}$ & - \\
\hline Albumin & $8.858 \mathrm{c}$ & +0.089 & $8.947 b$ & $+0.159 *$ & $9.106 \mathrm{~b}$ & - \\
\hline Urea & $8.945 b$ & $+0.172 *$ & $9.117 \mathrm{a}$ & +0.038 & $9.155 b$ & - \\
\hline \multicolumn{7}{|c|}{ Glutamate dehydrogenase activity (arbitrary units) ${ }^{3}$} \\
\hline Control & 1.146 & +0.183 & 1.329 & +0.623 & 1.952 & $1.397 \mathrm{a}$ \\
\hline Albumin & 1.257 & +0.262 & 1.519 & +0.600 & 2.119 & $1.551 \mathrm{a}$ \\
\hline Urea & 0.937 & +0.671 & 1.608 & +0.309 & 1.917 & $1.426 \mathrm{a}$ \\
\hline Mean 2 & - & $+0.435^{*}$ & - & $+0.546^{*}$ & - & - \\
\hline
\end{tabular}

Table 5 - Concentration of ammonia nitrogen in rumen fluid ( $\mathrm{mg} / \mathrm{dL})$ according to time after supplementation and nitrogen sources (in situ experiment)

\begin{tabular}{|c|c|c|c|c|c|c|}
\hline \multirow[b]{2}{*}{ Nitrogen source } & \multicolumn{5}{|c|}{ Time (hours) } & \multirow[b]{2}{*}{ Mean ${ }^{1}$} \\
\hline & $6^{1}$ & $\Delta_{6-12}{ }^{2}$ & $12^{1}$ & $\Delta_{12-24^{2}}$ & $24^{1}$ & \\
\hline Control & 9.97 & -0.54 & 9.43 & -0.84 & 8.59 & $9.33 b$ \\
\hline Albumin & 36.22 & -20.72 & 15.50 & -6.05 & 9.45 & $20.39 \mathrm{a}$ \\
\hline Urea & 47.04 & -25.20 & 21.84 & -10.93 & 10.91 & $26.60 \mathrm{a}$ \\
\hline Mean $^{2}$ & - & $-15.49 *$ & - & $-5.94 *$ & - & \\
\hline
\end{tabular}

${ }^{1}$ Means in the column followed by different letters differ according to the profile analysis $(\mathrm{P}<0.10)$.

2 Differentials followed by $*$ are different from zero according to the profile analysis $(\mathrm{P}<0.10)$.

\section{Discussion}

In tests conducted in situ, the $\mathrm{pH}$ was not affected by the inclusion of nitrogenous compounds and, on average, the value of the $\mathrm{pH}$ was 6.55 (Table 4). In animals fed high forage diets, the change in $\mathrm{pH}$ due to supplementation is relatively small, showing no negative effect on cellulolytic bacteria growth. Therefore, under these conditions, a change in $\mathrm{pH}$ does not seem to be caused by supplementation with nitrogenous compounds.

Conversely, products that are generated in vitro cannot be removed and the AN concentration tends to be greater than in tests conducted in vivo or in situ. The addition of urea resulted in higher AN concentrations during all incubation periods of the in vitro test (Table 2). The AN obtained from the protein supplemented inoculum was higher than the control after six hours of incubation; however, these concentrations were always lower than those obtained with urea (Table 2).
Due to the absorption of AN by the rumen epithelium, concentrations of $\mathrm{AN}$ in vivo increased after supplementation and then decreased over time (Table 5). However, due to nitrogen cycling mechanisms, AN concentrations were always higher than the control when exogenous sources of nitrogen were added to the system (Table 5); even the supplied forage contained CP levels above $13 \%$. Higher concentrations of AN makes the rumen a favourable environment for fibrolytic bacteria growth because they use AN as the major source of nitrogen.

Despite the increased availability of AN when sources of protein are added, an increase in the in vitro concentration of microbial protein compared with control was observed only in the sixth hour of incubation (Table 2). This may be explained by the higher concentration of AN in the first hours after supplementation.

Overall, the addition of all nitrogenous compounds in this study led to similar concentrations of microbial protein (Table 2). This behaviour reinforces the existence of 
competition between groups of microbial species (Carvalho et al., 2011) because the favouring of a particular group reduces the production and efficiency of the other group, leading to a redistribution of microbial production among species groups in the environment.

Cellulose is a linear polymer composed of $\beta-1,4$ glycosidic bonds with a simple primary structure and complex tertiary structure. In some regions of cellulose, the polymer chain is highly ordered and strongly linked by hydrogen bonds, forming crystalline arrays. Alternatively, cellulose molecules may loosely arrange to form an amorphous region (Bhat \& Hazlewood, 2001). The crystalline region of cellulose is rigid and is almost inaccessible to cellulases, while the amorphous region is easily attacked by endoglucanases or exoglucanases (Sinitsyn et al., 1990). Therefore, the complete hydrolysis of cellulose is accomplished by an enzyme system capable of acting on the crystalline and amorphous regions.

The cellulase system contains endoglucanases, exoglucanases or cellobiohydrolase, and $\beta$-glucosidase or cellobiase. The activity of endoglucanases is usually determined by the measurement of the amount of reducing sugars released from carboxymethyl cellulose (Wood \& Bhat, 1988).

Cellulases of bacteria may adopt different mechanisms for the cellulose hydrolysis. Anaerobic bacteria, including species in the rumen, have an enzyme complex with a high molecular weight called cellulosomes (Beguin \& Lemaire, 1996). According to Bhat \& Hazlewood (2001), cellulases are inducible enzymes; however, once the polysaccharide cannot enter the cell, low levels of cellulases are constitutively produced. Thus, cellulose hydrolysis produces soluble sugars that are converted into inducers of cellulase transcription or become inducers upon entering the cell (Biely, 1993; Kubicek et al., 1993). Therefore, the inhibition of the cellulose hydrolysis indirectly leads to lower enzyme synthesis, which enhances inhibition.

The inclusion of albumin inhibited CMCase activity in situ (Table 4). Moreover, the inclusion of urea favoured the activity of this enzyme in vitro (Table 2). These results corroborate those obtained by Firkins et al. (1991), who verified the stimulation of CMCase activity with the urea supplementation.

It should be noted that the CMCase activity not only reflects the extent of degradation but also emphasises small differences in the degradation rate, conferring greater sensitivity for comparing effects of different treatments on degradation dynamics of fibrous substrates (Silva et al., 1987).

Although some authors have attributed the increase in AN levels in the rumen as a possible advantage of the use of urea as a supplement (Paulino et al., 2008; Zorzi et al., 2009), the results obtained in situ (Table 5) show that protein and non-protein sources were equally effective in increasing the AN concentration. Thus, the lower in vivo CMCase activity with albumin addition does not appear to be associated with the availability of nitrogen precursors for fibrolytic bacteria growth.

The in vitro addition of casamino acids resulted in levels of CMCase activity similar to those obtained with urea (Table 2). This compound is produced by the hydrolysis of casein, which results in free amino acids. Under this assumption, the inhibition in the use of fiber by supplementation with true protein does not appear to be due to the nature of this nutrient but to the assimilation mechanisms and competition of the microorganisms.

Rumen bacteria are capable of using peptides at faster rates than free amino acids. This is because the energy used to transport a peptide containing several amino acids is the same used to transport one single free amino acid (Chen et al. 1987a; 1987b; Russell et al. 1991). Some studies indicate that the final products of protein degradation are peptides and not free amino acids. Thus, transport would be the limiting step in protein metabolism (Hino \& Russell, 1986).

However, in the present study, competition between fibrolytic and non-fibrolytic species may exist (Carvalho et al., 2011) and the enhancement of fibrolytic bacteria (evidenced by an increase in CMCase activity) may be explained by considering the less favoured amylolytic bacteria, which use peptides more efficiently. Moreover, competition for nitrogenous compounds may favour cellulolytic bacteria when amino acids are provided because peptide assimilation by non-fibrolytic bacteria decreases the competitiveness of fibrolytic bacteria, which require more available nitrogen sources, such as amino acids and ammonia.

Different enzyme systems may be used in the ammonia assimilation and the predominance of a particular system depends on the concentration of AN in the environment and intracellular accumulation of ammonia.

The enzyme system with the greatest affinity for ammonia is the glutamine synthetase-glutamate synthase (GS-GOGAT) (White, 2000). Ammonia is initially incorporated into glutamine, where glutamate is used as a substrate. The incorporation of ammonia occurs with the concomitant hydrolysis of ATP. The $\mathrm{NH}_{2}$ is then transferred to $\alpha$-oxoglutarate, which forms two glutamate molecules (Wallace et al., 1997). If the concentration of ammonia is low, microbial growth is reduced because ATP is diverted from growth to the process of nitrogen assimilation by 
GS-GOGAT. Erfle et al. (1977) verified GS-GOGAT activity under low ammonia concentrations, but the activity of this enzyme was not significant under high concentrations.

When there are high concentrations of ammonia, the main pathway of nitrogen assimilation is glutamate dehydrogenase (GDH) (White, 2000). Low affinity enzyme systems for the ammonia assimilation present in rumen microorganisms include NADP-glutamate dehydrogenase (GDH-NADP), GDH-NAD and alanine dehydrogenase (Wallace et al., 1997). However, GDH-NAD is the main enzymatic system involved in the ammonia assimilation in the rumen (Chalupa et al., 1969). Schaefer et al. (1980) determined the saturation constant of ammonia in pure cultures and concluded that the ammonia saturation constant $\left(\mathrm{k}_{\mathrm{s}}\right)$ varied between 15 and $45 \mathrm{mM}$ for the majority of the ruminal species. These authors also determined that the ammonia assimilation by bacteria through the ATP-dependent system may decrease the ATP efficiency in the cell, up to $14 \%$. It is important to realize that enzyme activity constitutes an estimate of the metabolic potential and may not reflect the actual rates of product formation. The utilisation of rumen ammonia is also controlled by other factors such as the availability of energy and cofactors, substrate concentration and bacterial membrane permeability (Chalupa et al., 1969).

The activity of GDH was higher in the treatments containing supplemental sources of nitrogenous compounds in vitro (Table 2). This may be due to a higher concentration of AN in these treatments. The $\mathrm{k}_{\mathrm{m}}$ of GDH for ammonia is 20 to $33 \mathrm{mM}$, which corresponds to 34 to $56 \mathrm{mg} / \mathrm{dL}$, respectively (Erfle et al., 1977; Wallace, 1979).

Furthermore, no difference in the GDH activity was detected among treatments in situ (Table 4). Chalupa et al. (1969) obtained similar results by supplementing sheep with urea and soybean meal.

Paulino et al. (2008) speculated that the increase in the concentration of AN in the rumen upon supplementation with urea could increase GDH activity, allowing optimal use of energy for microbial growth. However, the results obtained in situ (Table 4) indicated that supplementation did not alter GDH activity in animals fed with high-quality forage, even at AN concentrations below the $\mathrm{k}_{\mathrm{m}}$ of this enzyme, as observed in the control treatment (Table 5).

Adding this pattern to arguments presented before, the lower activity of CMCase observed in situ with true protein supplementation (Table 4) and the higher CMCase activity observed in vitro with urea supplementation (Table 2) cannot be due to a change in the balance of ATP-dependent and -independent enzymatic systems during microbial nitrogen assimilation.
However, there are several studies where the "protein effect" was observed (Mould et al., 2005; Paez-Bernal, 2007; Costa et al., 2009; Zorzi et al., 2009), which bring into evidence the demand for a causal explanation about that.

A possible explanation for the behavior observed in this study could be taken from the microbial protein concentration in the medium (Table 2). The constant concentration after 12 hours demonstrates that equilibrium between the growth of fibrolytic and non-fibrolytic species seems to exist in the environment according to nitrogen source.

In a recent study, Carvalho et al. (2011) reported that true protein supplementation stimulates the growth of nonfibrolytic bacteria possibly because this nitrogen source is not well used by fibrolytic bacteria.

Using this assumption, true protein supplementation seems to constrain fibrolytic activity as a result of stimulus on non-fibrolytic bacteria growth, which increases competition in the rumen rather than alterations on mechanisms of ammonia assimilation.

\section{Conclusions}

Supplementation based on true protein can cause detrimental effects on the microbial utilisation of insoluble fibrous substrates. This pattern seems to be caused by an increase in competition between non-fibrolytic and fibrolytic bacteria. Moreover, non-protein nitrogenous compounds enhance cellulose hydrolysis, which could be resultant from an increase in the competitiveness of fibrolytic bacteria.

\section{References}

BEGUIN P.; LEMAIRE, M. The cellulosome: an exocellular, multiprotein complex specialized in cellulose degradation. Critical Reviews in Biochemistry, v.31, p.201-236, 1996.

BIELY, P. Biochemical aspects of the production of microbial hemicellulases. In: COUGHLAN, M.P.; HAZLEWOOD, G.P. (Eds.) Hemicellulose and hemicellulases. London: Portland Press, 1993. p.29-51.

BHAT, M.K.; HAZLEWOOD, G.P. Enzymology and other characteristics of cellulases and xylanases. In: BEDFORD, M.R.; PARTRIDGE, G.G. (Eds.) Enzymes in farm animal nutrition. Wiltshire: CABI Publishing, 2001.p.11-60.

BRADFORD, M. Photometric methods for protein determination. Procedures and materials. Animal Biochemistry, v.72, p.248-254, 1976.

BROWN, C.M.; MACDONALD-BROWN, D.S.; MEERS, J.L. Physiological aspects of microbial inorganic nitrogen metabolism. Advances in Microbiology Physiology, v.11, p.1-52, 1974.

CARVALHO, I.P.C.; DETMANN, E.; MANTOVANI, H.C. et al. In vitro growth and antimicrobial activity of lactic acid bacteria from rumen fluid according to energy or nitrogen source. Revista Brasileira de Zootecnia, v.40, p.1260-1265, 2011. 
CASALI, A.O.; DETMANN, E.; VALADARES FILHO, S.C. et al. Influência do tempo de incubação e do tamanho de partículas sobre os teores de compostos indigestíveis em alimentos e fezes bovinas obtidos por procedimentos in situ. Revista Brasileira de Zootecnia, v.37, p.335-342, 2008.

CHANEY, A.L.; MARBACH, E.P. Modified reagents for determination of urea and ammonia. Clinical Chemistry, v.8, p.130-132, 1962.

CHALUPA, W.; CLARK, J.; OPLIGER P. et al. Ammonia metabolism in rumen bacteria and mucosa from sheep fed soy protein or urea. Journal of Nutrition, v.100, p.161-169, 1969.

CHEN, G.; RUSSELL, J.B.; SNIFFEN, C.J. A procedure for measuring peptides in rumen fluid and evidence that peptide uptake can be a rate-limiting step in ruminal protein degradation. Journal of Dairy Science, v.70, p.1211-1219, 1987a.

CHEN, G.; RUSSELL, J.B.; SNIFFEN, C.J. Effect of hydrophobicity on utilization of peptides by ruminal bacteria in vitro. Applied and Environmental Microbiology, v.53, p.2021-2025, 1987 b.

COSTA, V.A.C.; DETMANN, E.; VALADARES FILHO, S.C. et al. In vitro degradation of neutral detergent fiber from high-quality tropical forage according to supplementation with protein and (or) carbohydrates. Revista Brasileira de Zootecnia, v.38, p.1803-1811, 2009.

CURI, P.R. Análises de medidas repetidas em experimentos biológicos. Revista Brasileira de Estatatística, v.41, p.137-150, 1980.

ERFLE, J.D.; SAUER, F.D.; MAHADEVAN, S. Effect of ammonia concentration on activity of enzymes of ammonia assimilation and on synthesis of amino acids by mixed rumen bacteria in continuous culture. Journal of Dairy Science, v.60, p.1064-1071, 1977.

FARENZENA, R.; KOZLOSKI, G.V.; CASTAGNINO, P.S. et al. Metodologia para determinação da atividade enzimática de bactérias fibrolíticas ruminais: uso do ditiotreitol ou mercaptoetanol como antioxidantes, com ou sem tetracloreto de carbono. In: REUNIÃO ANUAL DA SOCIEDADE BRASILEIRA DE ZOOTECNIA, 45., 2008, Lavras. Anais... Lavras: Sociedade Brasileira de Zootecnia, 2008 (CD-ROM).

FIRKINS, J.L.; BOWMAN, J.G.P.; WEISS, W.P. et al. Effects of protein, carbohydrate, and fat sources on bacterial colonization and degradation of fiber in vitro. Journal of Dairy Science, v. 74, p.4273-4283, 1991.

HINO, T.; RUSSELL, J.B. Relative contributions of ruminal bacteria and protozoa to the degradation of protein in vitro. Journal of Animal Science, v.64, p.261-270, 1986.

KING, J. Glutamate dehydrogenase - Colorimetric assay. In: BERGMEYER, H.U (Ed.). Methods of enzymatic analysis. 2.ed. New York: Academic Press, 1974. p.656-659.

KUBICEK, C.P.; MESSNER, R.; GRUBER, F. et al. The Trichoderma reesei cellulase regulatory puzzle - from the interior life of a secretory fungus. Enzyme and Microbial Technology, v.15, p.90-99, 1993.

LITTELL, R.C.; FREUND, R.J.; SPECTOR, P.C. SAS system for linear models. Cary: SAS Institute, 1991. 329p.

MARCONDES, M.I.; GIONBELLI, M.P.; VALADARES FILHO, S.C. et al. Protein requirements of zebu cattle. In: VALADARES
FILHO, S.C.; MARCONDES, M.I.; CHIZZOTTI, M.L. et al. (Eds.) Nutrient requirements of zebu beef cattle BRCORTE. Viçosa, MG: DZO-UFV, 2010. p.107-126.

MERTENS, D.R. Gravimetric determination of amylase-treated neutral detergent fiber in feeds with refluxing beakers or crucibles: collaborative study. Journal of AOAC International, v.85, p.1217-1240, 2002.

MILLER, G.L.; BLUM, R.; GLENNON, W.E et al. Measurement of carboxymethilcellulase activity. Analytical Biochemistry, v.2, p.127-132, 1960.

MOULD, F.L.; MORGAN, R.; KLIEM, K.E. et al. A review and simplification of the in vitro incubation medium. Animal Feed Science and Technology, v.123/124, p.155-172, 2005.

PAEZ-BERNAL, D.M. Dinâmica de degradação in vitro da fibra em detergente neutro de capim-braquiária em função de suplementação com diferentes fontes de compostos nitrogenados e carboidratos. 2007. 49f. Dissertação (Mestrado em Zootecnia) - Universidade Federal de Viçosa, Viçosa, MG.

PAULINO, M.F.; DETMANN, E.; VALENTE, E.E.L. et al. Nutrição de bovinos em pastejo. In: SIMPÓSIO SOBRE MANEJO ESTRATÉGICO DA PASTAGEM, 4., 2008, Viçosa, MG. Anais... Viçosa, MG: DZO-UFV, 2008. p.131-169.

RUSSELL, J.B.; ONODERA, R.; HINO, T. Ruminal protein fermentation: new perspectives on previous contradictions. In: TSUDA, T.; SASAKI, Y.; KAWASHIMA, R. (Eds.) Physiological aspects of digestion and metabolism in ruminants. New York: Academic Press, 1991. p.681-697.

SCHAEFER, D.M.; DAVIS, C.L.; BRYANT, M.P. Ammonia saturation constants for predominant species of rumen bacteria. Journal of Dairy Science, v.63, p.1248-1263, 1980.

SINITSYN, A.P.; GUSAKOV, A.V.; YU VLASENKO, E. Effect of structural and physico-chemical features of cellulosic substrates on the efficiency of enzymatic hydrolysis. Applied Biochemistry and Biotechnology, v.30, p.43-59, 1990.

SILVA, A.T.; WALLACE, R.J.; ØRSKOV, E.R. Use of particle-bound microbial enzyme activity to predict the rate and extent of fiber degradation in the rumen. British Journal of Nutrition, v.57, p.407-415, 1987.

WALLACE, R.J. Effect of ammonia concentration on the composition, hydrolytic activity and nitrogen metabolism of the microbial flora of the rumen. Journal of Applied Microbiology, v.47, p.443-455, 1979

WALLACE, R.J.; ONODERA, R.; COTTA, M.A. Metabolism of nitrogen-containing compounds. In: HOBSON, P.N.; STEWART, C.S. (Eds.) The rumen microbial ecosystem. 2.ed. London: Chapman Hall, 1997. p.283-328.

WHITE, D. The physiology and biochemistry of prokaryotes. 2.ed. New York: Oxord University Press, 2000. 565p.

WOOD, T.M.; BHAT, K.M. Methods for measuring cellulase activities. In: WOOD, W.A.; KELLOGG, S.T. (Eds.) Methods in enzymology. London: Academic Press, 1988. p.87-112.

ZORZI, K.; DETMANN, E.; QUEIROZ, A.C. et al. In vitro degradation of neutral detergent fiber of high-quality tropical forage according to supplementation with different nitrogenous compounds. Revista Brasileira de Zootecnia, v.38, p.964-971, 2009 . 